\title{
Effect of sowing date, irrigation and mulch on thermal time requirement and heat use efficiency of maize (Zea mays L.)
}

\author{
HARLEEN KAUR, P.K. KINGRA and SOM PAL SINGH \\ Department of Climate change and Agricultural Meteorology \\ Punjab Agricultural University, Ludhiana - 141004 \\ e-mail:pkkingra@pau.edu
}

\begin{abstract}
The field experiments was carried out for three years (2015 to 2017) at the Research Farm, Department of Climate Change and Agricultural Meteorology, Punjab Agricultural University, Ludhiana with maize variety $\mathrm{PMH}-1$ sown on three dates $\left(D_{1}\right.$-Third week of May, $D_{2}$-Second week of June and $D_{3}$ First week of July) under two irrigation regimes ( $\mathrm{I}_{1}=\mathrm{IW}:$ :CPE 1.0 and $\mathrm{I}_{2} \mathrm{IW}:$ CPE 0.75$)$ and mulch application $\left(\mathrm{M}_{1}\right.$ : straw mulch @ 5 tha $^{-1}$ and $\mathrm{M}_{2}$ : without mulch) in a split plot design. Results revealed that the early sown crop(third week of May) took higher number of days and heat units to attain various phenophases. Maize variety $\mathrm{PMH}-1$ consumed maximum heat units of $1952^{\circ} \mathrm{C}$ days for maturity under early sown condition. The heat use efficiency was highest $\left(3.04 \mathrm{~kg} \mathrm{ha}^{-10} \mathrm{Cday}^{-1}\right)$ for the crop sown during June. Among irrigation regimes, the HUE was higher $\left(2.89 \mathrm{~kg} \mathrm{ha}^{-10} \mathrm{C}\right.$ day $\left.^{-1}\right)$ in IW: CPE $=0.75$ level of irrigation as compared to IW: CPE $=1.00\left(2.81 \mathrm{~kg} \mathrm{ha}^{-10} \mathrm{Cday}^{-1}\right)$ and higher HUE was obtained with mulch application $\left(\mathrm{M}_{1}\right)\left(2.92 \mathrm{~kg} \mathrm{ha}^{-10} \mathrm{Cday}^{-1}\right)$ as compared to without mulch $\left(\mathrm{M}_{2}\right)\left(2.76 \mathrm{~kg} \mathrm{ha}^{-10} \mathrm{Cday}^{-1}\right)$. The sowing of maize crop during second week of June with irrigation of IW: CPE 0.75 under mulch application have been found to be the most efficient for heat utilisation.
\end{abstract}

Key words: Maize, phenology, heat units, heat use efficiency, maize, mulch, irrigation

Temperature plays most important role in almost all biological processes of crop plants and hence the growth and development of living biota. Under changing climatic conditions, various management options viz. date of sowing; irrigation, mulch etc.are important production components which can be manipulated to counter the adverse effects of environmental stresses. Matching the phenology of the crop to the duration of favourable environmental conditions to avoid the periods of stress is crucial for maximum yield and resource use efficiency under changing climate.

The growing degree days (GDD) are often used to relate crop growth and yield to meteorological conditions prevailing during crop growing period. Crop sown on different dates and irrigation givenat different crop growth stages provides sufficient information to find out the best option with logical understanding (Sharangi and Roychowdhury, 2014). Heat and radiation use efficiencies in terms of dry matter or yields are important aspects which have great practical applications. Hence, the knowledge on the growing degree days, heliothermal units (HTU), photothermal units (PTU) and heat use efficiency (HUE) forms the basis to understand the phenology and the appropriate planting times for different crop varieties over the spatial and temporal scale (Sreenivas et al., 2010).In view of this, the present investigation was made to evaluate the effect of different management options viz sowing time, mulch application and irrigation levels etc on heat utilisation efficiency of maize so that suitable adaptation measures can be explored to improve its heat use efficiency in view of changing climatic conditions.

\section{MATERIALS AND METHODS}

\section{Experimental details}

The field experiment was carried out during kharif 2015, 2016 and 2017 at the Research Farm, Department of Climate Change and Agricultural Meteorology, Punjab Agricultural University, Ludhiana with maize variety PMH1 sown on three dates viz. $D_{1}$-Third week of May, $D_{2}-$ Second week of June and $\mathrm{D}_{3}$ - First week of Julyunder two irrigation levels i.e. irrigation at IW: CPE of $1.00\left(\mathrm{I}_{1}\right)$ and $0.75\left(\mathrm{I}_{2}\right)$ and mulch viz.application of straw mulch@5 tha $\mathrm{t}^{-1}\left(\mathrm{M}_{1}\right)$ and without mulch $\left(\mathrm{M}_{2}\right)$ in split plot design (SPD) with dates of sowing and mulch in main plots and irrigation levels in the sub-plots.

The days taken to attain different phenological stages 
namely emergence, 8 leaf stage, knee-high stage, tasselling, silking and physiological maturity were recorded through visual observations. Data on tasselling and silking was taken, when 50 per cent plants developed tassel and silk. The yellowing of cobs in around 90 per cent plants was taken as physiological maturity stage. Grain and straw yield was recorded from net plot at the time of harvesting of the crop. Dailymaximum and minimum temperature and sunshine hours during crop growing period were recorded from the agrometeorological observatory.

\section{Heat units}

The growing degree days (GDD)was calculated following Nuttonson (1955); taking base temperature of $10^{\circ} \mathrm{C}$.

$\operatorname{GDD}=\left(\mathrm{T}_{\max }+\mathrm{T}_{\text {min }}\right) / 2-\mathrm{T}_{\mathrm{b}}$

Where,

$$
\begin{aligned}
\mathrm{T}_{\text {max }} & =\text { Daily maximum temperature }\left({ }^{\circ} \mathrm{C}\right) \\
\mathrm{T}_{\min } & =\text { Daily minimum temperature }\left({ }^{\circ} \mathrm{C}\right) \\
\mathrm{T}_{\mathrm{b}} & =\text { Base temperature }(10 \mathrm{U} \mathrm{C} \text { for maize })
\end{aligned}
$$

The heliothermal units (HTU) was calculated as;

$\mathrm{HTU}=\mathrm{GDD} \times$ Actual bright sunshine hours $\left({ }^{\circ} \mathrm{C}\right.$ day hours $)$ The photothermal units (PTU) was calculated as;

$\mathrm{PTU}=\mathrm{GDD} \times$ Day length $\left({ }^{\circ} \mathrm{C}\right.$ day hours $)$

and the heat use efficiency (HUE) was calculated as;

$$
\text { Heat use efficiency }\left(\mathrm{kg} \mathrm{ha}^{-10} \mathrm{C} \mathrm{day}^{-1}\right)=\frac{\text { Grain yield }\left(\mathrm{kg} \mathrm{ha}^{-1}\right)}{\operatorname{AGDD}\left({ }^{\circ} \mathrm{C} \text { day }\right)}
$$

Where, $\operatorname{AGDD}\left(\mathrm{kg} \mathrm{ha}^{-10} \mathrm{C}\right.$ day $\left.^{-1}\right)=$ Accumulated growing degree days.

\section{RESULTS AND DISCUSSION}

\section{Crop phenology}

Sowing time, irrigation and mulch application had significant effect on phenology of maize(Table 1). The maize cultivar PMH-1 took 92,87 and 78 days to attain physiological maturity under different sowing dates, the crop duration decreased with delay in sowing. Among the irrigation levels, the crop grown under IW: $\mathrm{CPE}=1.0$ consumed higher number of days than IW: $\mathrm{CPE}=0.75$ at all the crop growth stages with significant difference at emergence, 8-leaf stage, tasseling and silking. However, due to good distribution of rainfall during the crop season, no significant difference could be observed in the days taken to attain physiological maturity. Similarly, the mulch applied crop took higher no. of days to attain different phenological stages with significant differences at emergence, 8-leaf stage, silking and physiological maturity. Kingra et al., (2011) also reported that higher number of days taken by wheat crop to attain a particular physiological maturity under increased frequency of irrigation. Conversely under late sowing, reproductive growth as well as total crop duration was drastically reduced. Several studies in India have shown that a delay of 20 days in sowing could cause a delay in flowering by 8 days or upto 13 days (Brar et al., 2011).

\section{Growing degree days (GDD)}

Early sown crop (May) consumed significantly higher heat units $\left(1952^{\circ} \mathrm{C}\right.$ days $)$ as compared to June $\left(1796^{\circ} \mathrm{C}\right.$ days $)$ and $\operatorname{July}\left(1579^{\circ} \mathrm{C}\right.$ days $)$ sown crop to attain physiological maturity (Table 2). Gowda et al, (2013) also reported that timely sown maize (first fortnight of June) took significantly more number of days and heat units to complete physiological maturity as compared to subsequent sowings. Under irrigation treatment IW: $\mathrm{CPE}=1.0$, the crop took higher heat units to attain different stages, the differences being significant at emergence, 8-leaf stage, tasselling and silking. The crop consumed 1790 and $1771{ }^{\circ} \mathrm{C}$ days to attain physiological maturity under irrigation treatment $\mathrm{I}_{1}$ and $\mathrm{I}_{2}$, respectively. Under straw mulch, the crop had higher heat unit consumption to attain various crop growth stages with significant difference at emergence, 8-leaf state, silking and physiological maturity (Table 2).

\section{Heliothermal units}

Maize sown during third week of May consumed significantly higher heliothermal units $\left(14304^{\circ} \mathrm{C}\right.$ day hours $)$ attain physiological maturity as compared to June $\left(12134^{\circ} \mathrm{C}\right.$ day hours) and July $\left(10721{ }^{\circ} \mathrm{C}\right.$ day hours $)$ sown crop. Under irrigation treatment IW: $\mathrm{CPE}=1.0$, maize took higher heat units $\left(12501{ }^{\circ} \mathrm{C}\right.$ day hours $)$ as compared to IW: CPE-0.75 $\left(12273^{\circ} \mathrm{C}\right.$ day hours) to attain physiological maturity. Crop with application of straw mulch also recorded higher heliothermal units with significant differences at emergence and physiological maturity. Straw mulch applied crop consumed $12612^{\circ} \mathrm{C}$ day hours, whereas the crop without mulch consumed $12161^{\circ} \mathrm{C}$ day hours to attain physiological maturity (Table 3).

\section{Photothermal units (PTU)}

Early sown maize (May) took significantly higher photothermal units $\left(26807^{\circ} \mathrm{C}\right.$ day hours) to attain physiological maturity as compared to June $\left(24130^{\circ} \mathrm{C}\right.$ day 
Table 1:Days taken to various phenological stages of sown as infuenced by tretments (three years 2015 to 2017 mean).

\begin{tabular}{|c|c|c|c|c|c|c|}
\hline Treatment & Emergence & 8-leaf stage & Knee-high & Tasselling & Silking & $\begin{array}{r}\text { Physiological } \\
\text { maturity }\end{array}$ \\
\hline \multicolumn{7}{|l|}{ Dates of sowing } \\
\hline $\mathrm{D}_{1}$ (Third week of May) & 7 & 22 & 45 & 62 & 78 & 91 \\
\hline $\mathrm{D}_{2}$ (Second week of June $)$ & 6 & 20 & 43 & 58 & 73 & 86 \\
\hline $\mathrm{D}_{3}$ (First week of July) & 5 & 19 & 41 & 55 & 66 & 78 \\
\hline $\mathrm{CD}(\mathrm{p}=0.05)$ & 0.7 & 1.0 & 2.1 & 2 & 2.4 & 2 \\
\hline \multicolumn{7}{|l|}{ Irrigation levels } \\
\hline $\mathrm{I}_{1}(\mathrm{IW} / \mathrm{CPE}=1.00)$ & 7 & 21 & 44 & 59 & 73 & 86 \\
\hline $\mathrm{I}_{2}(\mathrm{IW} / \mathrm{CPE}=0.75)$ & 6 & 20 & 43 & 57 & 71 & 84 \\
\hline $\mathrm{CD}(\mathrm{p}=0.05)$ & 0.6 & 0.8 & NS & 1.1 & 1.9 & NS \\
\hline \multicolumn{7}{|l|}{ Mulch levels } \\
\hline $\mathrm{M}_{1}$ (with straw mulch@ $\left.@ 5 \mathrm{tha}^{-1}\right)$ & 6 & 20 & 44 & 59 & 73 & 87 \\
\hline $\mathrm{M}_{2}$ (without mulch) & 6 & 20 & 43 & 58 & 72 & 84 \\
\hline $\mathrm{CD}(\mathrm{p}=0.05)$ & 0.4 & 0.3 & NS & NS & 0.5 & 2.0 \\
\hline
\end{tabular}

Table 2: Accumulated growing degree days $\left({ }^{\circ} \mathrm{C}\right.$ day) at different stage of maize under different treatments (three years 2015 to 2017 mean).

\begin{tabular}{|c|c|c|c|c|c|c|}
\hline Treatment & Emergence & 8-leaf stage & Knee-high & Tasselling & Silking & $\begin{array}{r}\text { Physiological } \\
\text { maturity }\end{array}$ \\
\hline \multicolumn{7}{|l|}{ Dates of sowing } \\
\hline $\mathrm{D}_{1}$ (Third week of May) & 172 & 498 & 1011 & 1357 & 1679 & 1953 \\
\hline $\mathrm{D}_{2}$ (Second week of June) & 149 & 456 & 929 & 1252 & 1531 & 1797 \\
\hline $\mathrm{D}_{3}$ (First week of July) & 122 & 394 & 851 & 1123 & 1339 & 1579 \\
\hline $\mathrm{CD}(\mathrm{p}=0.05)$ & 16.2 & 21.7 & 45.9 & 47.0 & 47.2 & 50.0 \\
\hline \multicolumn{7}{|l|}{ Irrigation levels } \\
\hline $\mathrm{I}_{1}(\mathrm{IW} / \mathrm{CPE}=1.00)$ & 156 & 461 & 940 & 1266 & 1541 & 1790 \\
\hline $\mathrm{I}_{2}(\mathrm{IW} / \mathrm{CPE}=0.75)$ & 141 & 438 & 921 & 1224 & 1493 & 1772 \\
\hline $\mathrm{CD}(\mathrm{p}=0.05)$ & 13.2 & 16.5 & NS & 22.4 & 23.5 & NS \\
\hline \multicolumn{7}{|l|}{ Mulch levels } \\
\hline $\mathrm{M}_{1}$ (with straw mulch@5tha-1) & 153 & 458 & 941 & 1245 & 1534 & 1809 \\
\hline $\mathrm{M}_{2}$ (without mulch) & 143 & 442 & 921 & 1235 & 1499 & 1744 \\
\hline $\mathrm{CD}(\mathrm{p}=0.05)$ & 4.1 & 7.4 & NS & NS & 9.8 & 40.9 \\
\hline
\end{tabular}

hours) and $\operatorname{July}\left(20737^{\circ} \mathrm{C}\right.$ day hours) sown crop. Under irrigation treatment IW: CPE $=1.0$ the crop took higher photothermal units to attain different phenological stages with significant differences at emergence, 8-leaf stage, tasseling and silking. The crop consumed 24019 and 23763 ${ }^{\circ} \mathrm{C}$ day hours to attain physiological maturity under irrigation treatment $I_{1}$ and $I_{2}$, respectively. Crop with application of straw mulch also recorded higher photothermal units with significant differences at emergence, 8 leaf stage, silking and physiological maturity. Straw mulch applied crop consumed $24263^{\circ} \mathrm{C}$ day hours, whereas the crop without mulch consumed $23520^{\circ} \mathrm{C}$ day hours to attain physiological maturity (Table 4).

\section{Heat use efficiency (HUE)}

Heat use efficiency of maize was significantly higher in the crop sown in the second week of June $\left(3.04 \mathrm{~kg} \mathrm{ha}^{-10} \mathrm{C}\right.$ 
Table 3: Accumulated heliothermal units $\left({ }^{\circ} \mathrm{C}\right.$ day hr) at different stages of under different treatmets (three years $2015-2017$ mean).

\begin{tabular}{|c|c|c|c|c|c|c|}
\hline Treatment & Emergence & 8-leaf stage & Knee-high & Tasselling & Silking & $\begin{array}{r}\text { Physiological } \\
\text { maturity }\end{array}$ \\
\hline \multicolumn{7}{|l|}{ Dates of sowing } \\
\hline $\mathrm{D}_{2}$ (Second week of June) & 1302 & 3449 & 6425 & 8180 & 9939 & 12134 \\
\hline $\mathrm{D}_{3}$ (First week of July) & 935 & 2531 & 5142 & 6896 & 8492 & 10722 \\
\hline \multicolumn{7}{|l|}{ Irrigation levels } \\
\hline $\mathrm{I}_{1}(\mathrm{IW} / \mathrm{CPE}=1.00)$ & 1405 & 3723 & 6809 & 8752 & 10485 & 12501 \\
\hline $\mathrm{I}_{2}(\mathrm{IW} / \mathrm{CPE}=0.75)$ & 1274 & 3553 & 6676 & 8509 & 10275 & 12273 \\
\hline $\mathrm{M}_{2}$ (without mulch) & 1293 & 3582 & 6678 & 8566 & 10327 & 12162 \\
\hline $\mathrm{CD}(\mathrm{p}=0.05)$ & 36.2 & NS & NS & NS & NS & 316.6 \\
\hline
\end{tabular}

Table 4: Accumulated PTU $\left({ }^{\circ} \mathrm{C}\right.$ day hr) of maize (three years mean)

\begin{tabular}{|c|c|c|c|c|c|c|}
\hline Treatment & Emergence & 8-leaf stage & Knee-high & Tasselling & Silking & $\begin{array}{r}\text { Physiological } \\
\text { maturity }\end{array}$ \\
\hline \multicolumn{7}{|l|}{ Dates of sowing } \\
\hline $\mathrm{D}_{1}$ (Third week of May) & 2352 & 6923 & 14150 & 18899 & 23200 & 26808 \\
\hline $\mathrm{D}_{2}$ (Second week of June) & 2100 & 6428 & 12939 & 17112 & 20917 & 24131 \\
\hline $\mathrm{D}_{3}$ (First week of July) & 1721 & 5446 & 11561 & 15111 & 17818 & 20737 \\
\hline $\mathrm{CD}(\mathrm{p}=0.05)$ & 226.2 & 300.9 & 625.3 & 618.8 & 606.1 & 608.2 \\
\hline \multicolumn{7}{|l|}{ Irrigation levels } \\
\hline $\mathrm{I}_{1}(\mathrm{IW} / \mathrm{CPE}=1.00)$ & 2150 & 6426 & 13009 & 17314 & 20953 & 24019 \\
\hline $\mathrm{I}_{2}(\mathrm{IW} / \mathrm{CPE}=0.75)$ & 1955 & 6106 & 12757 & 16767 & 20337 & 23764 \\
\hline $\mathrm{CD}(\mathrm{p}=0.05)$ & 127.4 & 228.7 & NS & 293.6 & 302.1 & NS \\
\hline \multicolumn{7}{|l|}{ Mulch levels } \\
\hline $\mathrm{M}_{1}$ (with straw mulch @ $\left.5 \mathrm{tha}^{-1}\right)$ & 2125 & 6375 & 13013 & 17171 & 20864 & 24263 \\
\hline $\mathrm{M}_{2}$ (without mulch) & 1989 & 6157 & 12743 & 16910 & 20427 & 23520 \\
\hline $\mathrm{CD}(\mathrm{p}=0.05)$ & 57.3 & 102.6 & NS & NS & 383.3 & 496.6 \\
\hline
\end{tabular}

day $\left.^{-1}\right)$ but it decreased when sown earlyi.e.in third week of May $\left(2.69 \mathrm{~kg} \mathrm{ha}^{-10} \mathrm{C} \mathrm{day}^{-1}\right)$ or late in first week of July $(2.82$ $\mathrm{kg} \mathrm{ha}^{-10} \mathrm{C}$ day $^{-1}$ ) (Table 5). Khushwaha et al, (2010) also reported maximum heat use efficiency in the corn crop sown on 15 June. Among the irrigation levels, there was no significant difference but heat use efficiency was higher under IW: $\mathrm{CPE}=0.75\left(2.89 \mathrm{~kg} \mathrm{ha}^{-10} \mathrm{C} \mathrm{day}^{-1}\right)$ as compared to that under IW: $\mathrm{CPE}=1.0\left(2.81 \mathrm{~kg} \mathrm{ha}^{-10} \mathrm{C} \mathrm{day}^{-1}\right)$. Among the mulch levels, significantly higher HUE was found in the mulch applied crop (2.92 $\left.\mathrm{kg} \mathrm{ha}^{-1}{ }^{\circ} \mathrm{C} \mathrm{day}^{-1}\right)$ as compared to non-mulch $\left(2.76 \mathrm{~kg} \mathrm{ha}^{-1}{ }^{\circ} \mathrm{C} \mathrm{day}^{-1}\right)$. Girijesh et al, (2011) also reported higher heat use efficiency with the crop sown in first fortnight of June and it decreased with each successive delay in sowing.

\section{CONCLUSION}

The study concluded that sowing of crop in second 
Table 5: Heat use efficiency $\left(\mathrm{kg} \mathrm{ha}^{-10} \mathrm{C} \mathrm{day}^{-1}\right)$ of maize as influenced by different treatment (three years 2015-2017 mean).

\begin{tabular}{|c|c|c|c|}
\hline Treatments & Heat use $(\mathrm{mm})$ & Grain yield $\left(\mathrm{kgha}^{-1}\right)$ & Heat use efficiency $\left(\mathrm{kgha}^{-1{ }^{\circ}} \mathrm{C}_{\text {day }}{ }^{-1}\right)$ \\
\hline \multicolumn{4}{|l|}{ Dates of sowing } \\
\hline $\mathrm{D}_{1}$ (Third week of May) & 1953 & 5261 & 2.69 \\
\hline $\mathrm{D}_{2}($ Second week of June $)$ & 1797 & 5469 & 3.04 \\
\hline $\mathrm{D}_{3}$ (First week of July) & 1579 & 4458 & 2.82 \\
\hline $\mathrm{CD}(\mathrm{p}=0.05)$ & 50.1 & 409.9 & 0.17 \\
\hline \multicolumn{4}{|l|}{ Irrigation levels } \\
\hline $\mathrm{I}_{1}(\mathrm{IW} / \mathrm{CPE}=1.00)$ & 1790 & 5036 & 2.81 \\
\hline $\mathrm{I}_{2}(\mathrm{IW} / \mathrm{CPE}=0.75)$ & 1757 & 5090 & 2.89 \\
\hline $\mathrm{CD}(\mathrm{p}=0.05)$ & NS & 246.8 & NS \\
\hline \multicolumn{4}{|l|}{ Mulch levels } \\
\hline $\mathrm{M}_{1}$ (With straw mulch@5 5 tha $^{-1}$ ) & 1809 & 5295 & 2.92 \\
\hline $\mathrm{M}_{2}$ (Without mulch) & 1744 & 4831 & 2.76 \\
\hline $\mathrm{CD}(\mathrm{p}=0.05)$ & 40.9 & 312.7 & 0.14 \\
\hline
\end{tabular}

week of June with IW: CPE 0.75 and application of straw mulch@ 5 tha $^{-1}$ proved to be the most efficient for improving heat utilisation efficiency of maize. Such management options can be used effectively to manage climate change impacts on maize to sustain crop productivity and food security under changing climatic scenarios in future.

\section{REFERENCES}

Brar, S. K., Mahal, S. S., Brar, A. S., Vashist, K. K. and Buttar, G. S. (2011). Phenology, heat unit accumulation and dry matter partitioning behaviour of two cultivars transplanted on different dates. J. Agrometeorol., 13(2), 153-156.

Girijesh, G.K., Kumara Swamy, A.S., Sridhara, S., Dinesh Kumar, M., Vageesh, T.S. and Nataraju, S.P. (2011). Heat use efficiency and helio-thermal units for maize genotypes as influenced by dates of sowing under southern transitional zone of Karnataka state. Int. J. Sci. Nature, 2(3): 529-533.

Gowda, P. T., Halikatti, S. I. and Manjunatha, S. B. (2013). Thermal requirementof maize (Zeamays L.) as influenced by planting dates and cropping systems. Res. J. Agric. Sci., 4(2): 207-10.

Kingra, P.K, Mahey, R.K, Gill, K.K. and Singh, S.P. (2011). Thermal requirements and heat use efficiency of wheat under different irrigation levels. Indian J.Ecol.,38 (2):228-233.

Kushwaha, H. S., Prasoon, P., Rai, H. K. and Singh, R. S. (2010). "Agrometeorological Services for Farmer" Ed. Vyas PandeyAnand Agricultural University, Anandpp 23-28.

Nuttonson, M. Y.(1955). Wheat climate relationships and use ofphenology in ascertaining the thermal and Photothermal requirement of wheat. American Institute of Crop Ecology, Washington DC, pp 338.

Sharangi, A. B. and Roychowdhury, A. (2014). Phenology and yield of coriander as influenced by sowing dates and irrigation. The Bioscan, 9(4): 1513-1520.

Sreenivas, G., M. Devender Reddy and Reddy, D.R.(2010). Agro-meteorological indices in relation to phenology of aerobic rice. J Agrometeorol., 12 (2): 241-244. 